PAWEt CZAPLIŃSKI

Uniwersytet Szczeciński, Polska - University of Szczecin, Poland

BARBARA OSÓCH

Uniwersytet Szczeciński, Polska - University of Szczecin, Poland

\title{
Aktywność przedsiębiorcza studentów geografii i kierunków pokrewnych: wyniki ankietyzacji szkół wyższych Euroregionu Pomerania (Greifswald, Eberswalde, Szczecin)
}

\section{Entrepreneurial Activity of Students of Geography and Related Fields: Survey Results of the Universities in the Pomerania Euroregion (Greifswald, Eberswalde, Szczecin)}

\begin{abstract}
Streszczenie: Przedsiębiorczość jako efekt poszukiwania przewag konkurencyjnych współczesnych gospodarek stymuluje wzrost i rozwój społeczno-ekonomiczny różnych układów przestrzennych. Dlatego też kształtowanie aktywności przedsiębiorczej winno dokonywać się na wszystkich poziomach edukacji. W sposób szczególny dotyczy to studentów, którzy w większości przypadków nie podjęli jeszcze decyzji o swojej karierze zawodowej. Na przedsiębiorczość studencką działa wiele czynników. Jednym $\mathrm{z}$ nich jest otoczenie, $\mathrm{w}$ tym normy społeczne i kody kulturowe charakterystyczne dla różnych państw, regionów itp. Mogą one wpływać na cechy osobowościowe i sposoby myślenia, w tym myślenia przedsiębiorczego. Celem pracy była analiza aktywności przedsiębiorczej studentów kierunku geografia i kierunków pokrewnych w świetle podejścia kulturalistycznego. Głównym narzędziem pomiarowym była ankieta skierowana do studentów z Greifswaldu i Eberswalde (Niemcy) oraz ze Szczecina (Polska). W wyniku przeprowadzonego badania określono różnice w aktywności przedsiębiorczej studentów z Polski i Niemiec oraz wskazano na te cechy osobowościowe, które według badanych ułatwiają aktywność przedsiębiorczą $\mathrm{w}$ każdym z krajów. Jak wynika z przeprowadzonych badań, istnieją różnice w aktywności przedsiębiorczej polskich i niemieckich studentów. Podejmowane w trakcie studiów inicjatywy nie przekładają się na plany biznesowe, a skala i zakres tych prac w małym stopniu pokrywają się z zainteresowaniami studentów i podjętymi przez nich kierunkami studiów.
\end{abstract}

Abstract: Entrepreneurship as a result of seeking competitive advantages of modern economies stimulates the growth and socio-economic development of various spatial systems. Therefore, shaping entrepreneurial activity should be implemented at all levels of education. This particularly applies to students who in most cases are not yet decided on their professional careers. There are many factors affecting student entrepreneurship. One of them is the environment, including social norms and cultural codes specific to different countries, regions, etc. They can affect personality traits and ways of thinking, in- 
cluding entrepreneurial thinking. The aim of the study was to analyse the entrepreneurial activity of students of geography and related fields in the cultural approach. The main measurement tool was a survey addressed to students from Greifswald, Eberswalde (Germany) and Szczecin (Poland). As a result of the study, the differences in the entrepreneurial activity of students from Poland and Germany were determined, and personality traits that, according to the respondents, facilitate entrepreneurial activity in each country were identified. Research shows that there are differences in the entrepreneurial activity of Polish and German students. Initiatives taken during studies do not translate into business plans, and the scale and scope of the work undertaken do not coincide well with the interests and field of study undertaken.

Słowa kluczowe: Euroregion Pomerania; geografia; przedsiębiorczość; studenci

Keywords: entrepreneurship; geography; Pomerania Euroregion; students

Otrzymano: 25 października 2019

Received: 25 October 2019

Zaakceptowano: 31 marca 2020

Accepted: 31 March 2020

\section{Sugerowana cytacja/Suggested citation:}

Czapliński, P., Osóch, B. (2020). Aktywność przedsiębiorcza studentów geografii i kierunków pokrewnych: wyniki ankietyzacji szkół wyższych Euroregionu Pomerania (Greifswald, Eberswalde, Szczecin). Przedsiębiorczość - Edukacja [Entrepreneurship - Education], 16(1), 62-73. doi: $10.24917 / 20833296.161 .5$

\section{Wstęp}

Współczesna decyzja o podjęciu studiów na polskich uczelniach łączy się nie tylko ze świadomością kontynuowania edukacji, lecz także równocześnie z rozpoczęciem kariery zawodowej. Coraz częściej dochodzi bowiem do łączenia studiów stacjonarnych z pracą zarobkową. Motywy takiej decyzji są bardzo różne. Decyduje zwykle czynnik ekonomiczny, ale rośnie również świadomość konieczności inwestowania we własny rozwój, w czym ma pomagać zdobywanie praktycznych doświadczeń (Czyżewska, 2018; Ostoj, 2016). Nie zawsze jest to jednak aktywność zawodowa zgodna z kierunkiem studiów, jeszcze rzadziej jest to własna działalność gospodarcza. Zwykle podejmowane prace mają charakter doraźny i przypadkowy. Jedną z głównych przyczyn ostrożności studentów przed podjęciem własnej działalności gospodarczej, poza barierą finansową, jest mało efektywny system kształcenia w zakresie przedsiębiorczości (Safin, 2014). Taka sytuacja dotyczy w zasadzie wszystkich kierunków studiów, w tym również kierunków ekonomicznych (np. Roszkowska-Mądra, Parfieniuk, Studnicki, 2014). Warto jednak dodać, że przedsiębiorczość jako kompetencja kluczowa to nie tylko zdolność do zakładania własnej działalności gospodarczej. Jak wskazuje T. Rachwał: „kompetencje kluczowe stanowią połączenie wiedzy, umiejętności i postaw, których wszyscy potrzebują do samorealizacji i rozwoju osobistego, bycia aktywnym obywatelem, integracji społecznej oraz zatrudnienia" (Rachwał, 2019: 110). Dlatego też problem przedsiębiorczości studenckiej należy widzieć w znacznie szerszej perspektywie znaczeniowej, czasowej, a może również i przestrzennej, ponieważ zróżnicowane przestrzennie normy społeczne i kody kulturowe, w których funkcjonuje człowiek, determinują jego cechy osobowościowe i sposób myślenia, w tym myślenia przedsiębiorczego (Osóch, Czapliński, 2019). Ponadto przedmioty i działania wspierające 
studentów w zakresie przedsiębiorczości nie dają, przynajmniej w Europie, jednolitego obrazu (Komisja Europejska, 2008; Łuczka, 2011; Nowaczyk, Sobczak, 2019). Przypadek studentów, a potem absolwentów kierunku geografia ${ }^{1}$ jest o tyle szczególny, że ich atrakcyjność na rynku pracy jest bardzo umiarkowana, co powinno mobilizować ich do większej aktywności przedsiębiorczej, rozumianej za J.A. Timmonsem (1999) jako szansa rynkowa inspirująca i pobudzająca studenta do podjęcia działań związanych z założeniem własnej firmy. Ale aktywność przedsiębiorczą można rozumieć znacznie szerzej, w odniesieniu do postaw, intencji i zachowań przedsiębiorczych, w tym do planowania i podejmowania każdej pracy zarobkowej.

W nawiązaniu do tych przesłanek celem pracy była charakterystyka różnic w aktywności przedsiębiorczej studentów kierunku geografia i kierunków pokrewnych z Greifswaldu i Eberswalde (Niemcy) oraz ze Szczecina (Polska) w świetle podejścia kulturalistycznego, przy założeniu na wstępie istotności norm społecznych i kodów kulturowych obowiązujących w różnych społeczeństwach oraz faktu, że otoczenie (kraj), w którym funkcjonuje student, determinuje jego cechy osobowościowe i sposób myślenia. Sąd o istotnych i rzeczywistych różnicach w normach społecznych i kodach kulturowych Polaków i Niemców oparto na wynikach badań przeprowadzonych przez K. Wojciechowskiego (2005), I. Ścibiorską-Kowalczyk (2017) oraz A. Ładę (2018).

Ponadto za cel przyjęto identyfikację cech osobowościowych, które według badanych ułatwiają aktywność przedsiębiorczą. Ze względu na rozległość tematyczną i merytoryczną celem pracy nie było stworzenie gotowych profilów studenckiej aktywności przedsiębiorczej w Polsce i Niemczech, ale rozpoznanie przesłanek do ich stworzenia.

Do tak postawionego celu przypisano następującą hipotezę badawczą: normy społeczne i kody kulturowe obowiązujące w różnych społeczeństwach determinują aktywność przedsiębiorczą studentów.

\section{Założenia metodyczne badań}

Jako główne narzędzie badawcze zastosowano ankietyzację przeprowadzoną wśród studentów studiów stacjonarnych Uniwersytetu Szczecińskiego (kierunki: geografia, gospodarka przestrzenna, turystyka i rekreacja, geologia, bezpieczeństwo wodne), Uniwersytetu w Greifswaldzie (kierunki: geografia, geografia nauczycielska) oraz Szkoły Wyższej Zawodowej w Eberswalde (kierunki: gospodarka krajobrazowa i ochrona przyrody). Zdefiniowanie respondentów jako studentów geografii zapewniło spełnienie dwóch istotnych warunków metodycznych. Po pierwsze, pozwoliło na weryfikację aktywności przedsiębiorczych wśród osób, które nie mają jeszcze dużego doświadczenia w tym zakresie. Po drugie, umożliwiło uzyskanie realnego odzwierciedlenia zjawiska wśród studentów tej samej grupy kierunków.

Wybór miejsca badań na poziomie kraju miał charakter doboru celowego, ponieważ łączył się z wyborem euroregionu, w tym przypadku był to Euroregion Pomerania. Bliskość geograficzna i podobieństwo społeczno-ekonomiczne miały ograniczyć wpływ innych czynników na zachowania i wybory studentów. Aby zrealizować postawiony cel

\footnotetext{
${ }^{1} \mathrm{~W}$ celu większej czytelności tekstu w pracy pod pojęciem studentów geografii rozumie się studentów studiów stacjonarnych kierunku geografia oraz kierunków pokrewnych funkcjonujących w badanych ośrodkach w roku akademickim 2018/2019.
} 
na poziomie szkoły wyższej, zdecydowano się na badania we wszystkich ośrodkach akademickich, gdzie istnieje możliwość studiowania na kierunku geografia lub kierunkach pokrewnych. Stąd wybór do badań dwóch uczelni niemieckich z Eberswalde (Brandenburgia) i Greifswaldu (Meklemburgia-Pomorze Przednie) oraz Szczecina.

Głównym instrumentem pomiarowym była ankieta skierowana do studentów. Przeprowadzono ją $\mathrm{w}$ formie przekrojowego badania bezpośredniego $\mathrm{w}$ maju i czerwcu 2019 r. ${ }^{2}$ Z racji niewielkiej liczby studentów badanych kierunków zdecydowano się na badanie całej populacji we wszystkich trzech ośrodkach. Ostatecznie do dalszego etapu badań zakwalifikowano 119 ankiet z Polski oraz 84 ankiety z Niemiec (38 z Eberswalde i 46 z Greifswaldu). Stanowi to około $90 \%$ całej polskiej populacji i $71 \%$ dla populacji niemieckiej. Większość z badanych studentów to kobiety. Dla grupy polskiej to 59\% badanych, a dla grupy niemieckiej - $64 \%$ badanych. Zdecydowana większość wszystkich badanych (ok. 95\%) to mieszkańcy Euroregionu Pomerania.

Badanie przeprowadzono za pomocą ankiety sporządzonej w dwóch wersjach językowych: wersji polskiej i wersji niemieckiej. Kwestionariusz składał się z 17 pytań stanowiących zasadniczą część ankiety oraz 9 pytań zawartych w metryczce (pytania o obywatelstwo, narodowość, płeć, kierunek i rok studiów, miejsce zamieszkania, wykształcenie ojca i matki, liczbę rodzeństwa, wielkość miesięcznego utrzymania). Większość pytań stanowiły badania zamknięte i półotwarte i miała charakter kafeterii dysjunktywnej lub koniunktywnej. Wybrany typ pytań miał wyeliminować problemy językowe i ułatwić procedurę kodowania ankiet. Tylko jedno pytanie miało charakter otwarty. Ograniczeniem badawczym okazała się wybiórczość udzielanych odpowiedzi w grupie niemieckiej. Niektóre pytania, zwłaszcza z metryczki ankietowej, uznano za zbyt osobiste. Stąd znacznie mniejsza liczba ankiet tej grupy zakwalifikowana do dalszych badań.

Tematykę pytań przypisano do trzech szczegółowych problemów badawczych sformułowanych następująco:

1. Jakie są doświadczenia zawodowe studentów?

2. Czy studenci mają plany na własny biznes?

3. Jakie cechy osobowościowe ułatwiają podejmowanie aktywności przedsiębiorczej?

Problemy szczegółowe zagregowano do problemu głównego wyrażonego w pytaniu: Czy odmienne kody kulturowe i zróżnicowane normy społeczne wpływają na aktywność przedsiębiorczą studentów wybranych, podobnych kierunków studiów położonych $\mathrm{w}$ tym samym euroregionie?

Do ograniczeń badawczych należy zaliczyć masowy brak odpowiedzi na wybrane pytania w ankietach z Niemiec, co znacznie ograniczyło możliwości analizy porównawczej. Warto również podkreślić, że część pytań miała charakter deklaratywny, przez co otrzymane odpowiedzi przełożone na rzeczywistość, mimo wielu potwierdzeń w rzeczywistości, wydają się względne.

Po przeprowadzeniu badań terenowych zgromadzone dane poddano analizie. $\mathrm{W}$ tym celu stworzono macierz danych wejściowych, które poddano kodowaniu, a następnie przetworzeniu za pomocą arkusza kalkulacyjnego Microsoft Excel. Na podstawie uzyskanych wyników dokonano agregacji problemu oraz sformułowano wnioski.

\footnotetext{
${ }^{2}$ Badania ankietowe w Niemczech zostały przeprowadzone pod kierunkiem prof. dr. Wilhelma Steingrube z Uniwersytetu w Greifswaldzie.
} 
Wyniki badań

Z przeprowadzonych badań wynika, że polscy i niemieccy studenci przejawiają szeroko rozumianą aktywność przedsiębiorczą. Istnieją jednak między nimi znaczne różnice ilościowe i jakościowe. Zdecydowana większość Polaków (73\%) podejmuje prace zarobkowe równocześnie z nauką na studiach dziennych. W grupie niemieckiej taką deklarację złożyło 33\% badanych. Przyjmując, że polscy studenci pracują powszechnie, należy także dodać, że praca ta jest determinowana głównie chęcią uzyskania niezależności finansowej, rozumianej jako sukces w wymiarze ekonomicznym i psychologicznym.

Przeważająca część pracujących polskich studentów (65\%) pracuje na podstawie umowy-zlecenia i pośrednio wskazuje na transparentność swojego zatrudnienia. Nie jest to poziom zadowalający, ale może wynika z faktu, że większość studentów nie ma stałej pracy (83\%), co prowokuje do czasem mniej formalnych umów. W grupie niemieckiej 96\% pracujących studentów twierdzi, że pracuje na podstawie oficjalnej umowy-zlecenia, ale, co interesujące, w zdecydowanej większości (78\%) są to płatne praktyki zawodowe związane z kierunkiem studiów. Z takiej formy w Szczecinie korzystają tylko nieliczni studenci geologii $w$ ramach otrzymanego grantu zewnętrznego. W świetle powyższego nie dziwi zatem stwierdzenie, że prace zarobkowe podejmowane przez studentów polskich w $80 \%$ nie pokrywają się z wybranymi kierunkami studiów.

Należy przyjąć, że wszyscy studenci, który zadeklarowali wykonywanie prac zarobkowych, niezależnie od grupy, pracują w sektorze usług. Studentów geografii z Polski i Niemiec różni jednak wewnętrzna struktura zatrudnienia (rycina 1). Dla geografów ze Szczecina popularnym miejscem pracy są placówki związane z kulturą i rozrywką (30\%) oraz z gastronomią (27\%), gdzie zdecydowana większość z nich pełni funkcje pomocnicze. Natomiast tylko $1 / 4 \mathrm{z}$ nich prowadzi działalność związaną z edukacją, gdzie ich pozycja może być zdecydowanie ważniejsza i bardziej prestiżowa. Według uzyskanych odpowiedzi, do pozostałych miejsc zarobkowania polskich studentów geografii należy zaliczyć placówki sportowo-rekreacyjne i placówki handlowe oraz znacznie mniej oczywiste miejsca w obszarze bankowości, administracji oraz służby zdrowia. Tak duża różnorodność, a jednocześnie znaczna odległość merytoryczna do studiowanego kierunku sugerowałaby niedopasowanie wykonywanej pracy do własnych zainteresowań, tymczasem 48\% studentów deklaruje, że aktualnie wykonywana praca jest zgodna z ich zainteresowaniami.

Może to oznaczać dość przypadkowy wybór studiów lub świadomy wybór studiów, których celem jest zdobycie dyplomu przy relatywnie niskim nakładzie sił i środków, a dużej przyjemności studiowania (np. przez udział w ćwiczeniach terenowych) lub też traktowanie studiów jako dodatkowego hobby. Wreszcie, istnieje również taka interpretacja, że specyfika kierunku geografia ułatwia lub umożliwia odkrywanie i rozwijanie dodatkowych zainteresowań.

Poziom pokrycia zainteresowań i pracy zarobkowej w grupie niemieckich studentów geografii jest wyższy i wynosi 53\%. Jest to spowodowane wspomnianą wcześniej formą pracy, tj. płatnymi praktykami, znacznie mniejszą presją ekonomiczną oraz lepszym wykorzystywaniem potencjału wiedzy i umiejętności, którymi dysponuje geograf na niemieckim rynku pracy. Dlatego też poza pracą w szeroko pojętej edukacji geograficznej (53\%), niemieccy studenci geografii pracują również w sektorze kreatywnym (31\%), a tylko pojedyncze osoby np. w gastronomii. Przekłada się to również na poziom satysfakcji z otrzymywanego wynagrodzenia, ponieważ $89 \%$ pracujących niemieckich geografów jest 
zadowolonych z warunków finansowych swojej pracy. W przypadku studentów z Polski poziom zadowolenia wynosi 53\%, co jest podyktowane szerszym problemem płac w Polsce, a także postrzeganiem miejsca geografa na rynku pracy, niedoszacowaniem jego kompetencji oraz względami natury społeczno-kulturowej.

Drugi ważny problem podjęty w badaniach to intencje przedsiębiorcze sprowadzające się do pytania, jak jednostka postrzega i ocenia własne chęci oraz wykonalność swoich zamierzeń w kontekście uwarunkowań krajowych, w tym różnego otoczenia kulturowego. W odpowiedzi na pytanie o zawód, w którym chcieliby pracować studenci geografii, w grupie polskiej daje się zauważyć duża przewidywalność. Przejawia się to w prawidłowości, że skoro student studiuje geograficzną turystykę i rekreację, to jego plany nie wykraczają poza pracę związaną z turystyczną obsługą klienta, pilotażem, rezydenturą. Studenci geografii łączą swoją przyszłość z zawodem hydrologa, meteorologa, geologa, a ich miejscem pracy miałaby być instytucja badawcza, czasem praca $\mathrm{w}$ terenie lub w szkole. Studenci kierunku bezpieczeństwo wodne deklarują chęć pracy w ratownictwie i instruktażu wodnym, a studenci kierunku gospodarka przestrzenna swoje zawodowe plany wiążą z rzeczoznawstwem majątkowym. W ten sposób sami studenci utrwalają pewne stereotypy dotyczące postrzegania, kompetencji i miejsca pracy dla geografa w Polsce. Niemieccy studenci geografii odmiennie kreślą swoje plany zawodowe, wskazując na zawody, które związane są raczej z szeroko pojętą geografią społeczno-ekonomiczną i gospodarką przestrzenną. Stąd wymieniali takie zawody, jak planista, architekt krajobrazu, kartograf, specjalista w zakresie GIS lub w zakresie rozwoju regionalnego. Ponadto uznaną pozycją społeczną i zawodową cieszy się w Niemczech nauczyciel geografii, dlatego też dużo studentów jest zainteresowanych pracą w szkole, co w polskich warunkach nie zawsze jest postrzegane jako sukces zawodowy.

Mimo wyraźnych różnic w planach zawodowych studentów z Polski i Niemiec, w obu grupach dało się zauważyć dość dużą powściągliwość, a nawet niechęć do rozpoczęcia własnej działalności gospodarczej. Być może wynika to z uwarunkowań indywidualnych,

Rycina 1. Struktura zatrudnienia studentów polskich i niemieckich w sektorze usług

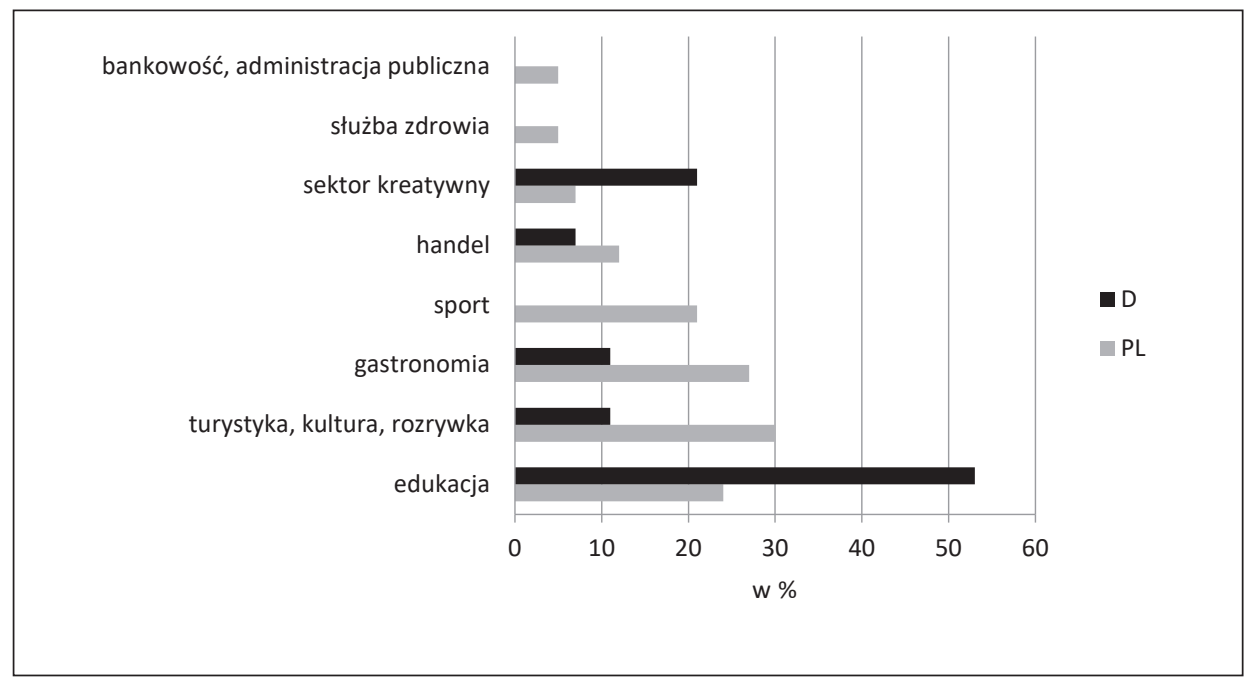

Źródło: opracowanie własne 
być może z określonego profilu osobowościowego kandydatów na tego typu studia, ale najprawdopodobniej jest to wynik braku lub mało skutecznej edukacji z zakresu przedsiębiorczości. Przesłankami do takiego wniosku są odpowiedzi na pytanie o to, co zniechęca studentów do podjęcia działalności przedsiębiorczej. Polscy studenci jako najważniejsze uznali obawę przed porażką oraz brak zasobów finansowych (po 47\%). Tak rozłożone akcenty informują o słabym rozpoznaniu własnych możliwości, także psychospołecznych, i małej wierze we własne siły. W przypadku grupy niemieckiej za najważniejszą barierę studenci uznali nadmierną biurokrację (48\%) oraz brak wiedzy o prowadzeniu firmy, co tylko potwierdza wcześniejsze ustalenia autorów, co do luk w wiedzy i umiejętnościach z zakresu przedsiębiorczości. W tym kontekście za interesujące uznano odpowiedzi na kolejne pytanie dotyczące pomysłu na własny biznes i czasu jego realizacji, które koresponduje z wcześniejszymi odpowiedziami (rycina 2). Ponownie widoczna różnica opinii dotyczy zarówno tego, czy studenci planują założyć własną firmę, jak i tego, kiedy planują ją założyć. W przypadku odpowiedzi na pierwszą część pytania ponad $65 \%$ studentów niemieckich zadeklarowało brak planów na własny biznes, przy niespełna 43\% głosów ze strony Polaków. Wynik ten nie musi świadczyć o zwiększonej aktywności przedsiębiorczej studentów ze Szczecina, ale o bardziej przewidywalnej ścieżce kariery zawodowej w Niemczech, która - w przeciwieństwie do warunków polskich - nie wymusza decyzji o samozatrudnieniu.

W przypadku odpowiedzi na drugą część pytania dotyczącą tego, kiedy student miałby rozpocząć działalność gospodarczą, polscy studenci wydają się być bardziej zorganizowani. Ich plany biznesowe są gotowe lub prawie gotowe w znacznie większym odsetku aniżeli plany ich niemieckich odpowiedników. Nie oznacza to jednak, że deklarowane plany są zawsze wynikiem świadomego planowania działań, tak charakterystycznych dla Niemców. Czasem jest to wynik działań doraźnych i przypadkowych, ale w duchu Timmonsowskiej aktywności przedsiębiorczej.

Rycina 2. Struktura odpowiedzi na pytanie: Czy i kiedy planujesz założyć własną firmę?

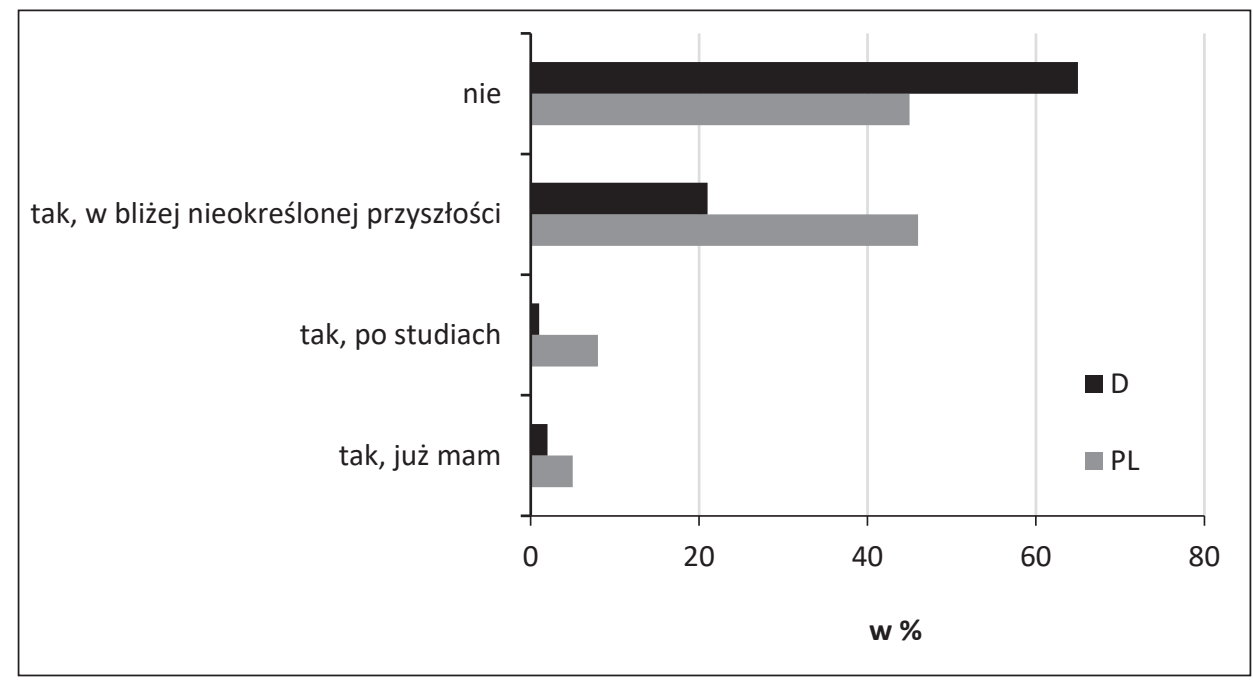

Źródło: opracowanie własne 
Rycina 3. Struktura cech osobowościowych ułatwiających wg niemieckich studentów podejmowanie aktywności przedsiębiorczych

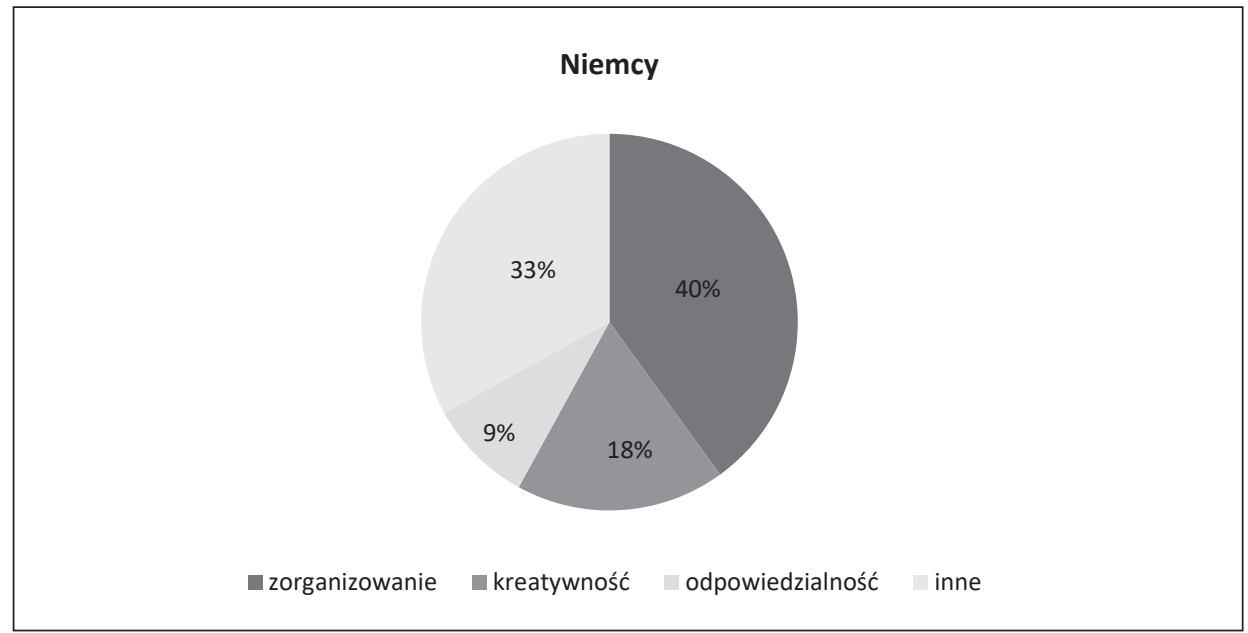

Źródło: opracowanie własne

Rycina 4. Struktura cech osobowościowych ułatwiających wg polskich studentów podejmowanie aktywności przedsiębiorczych

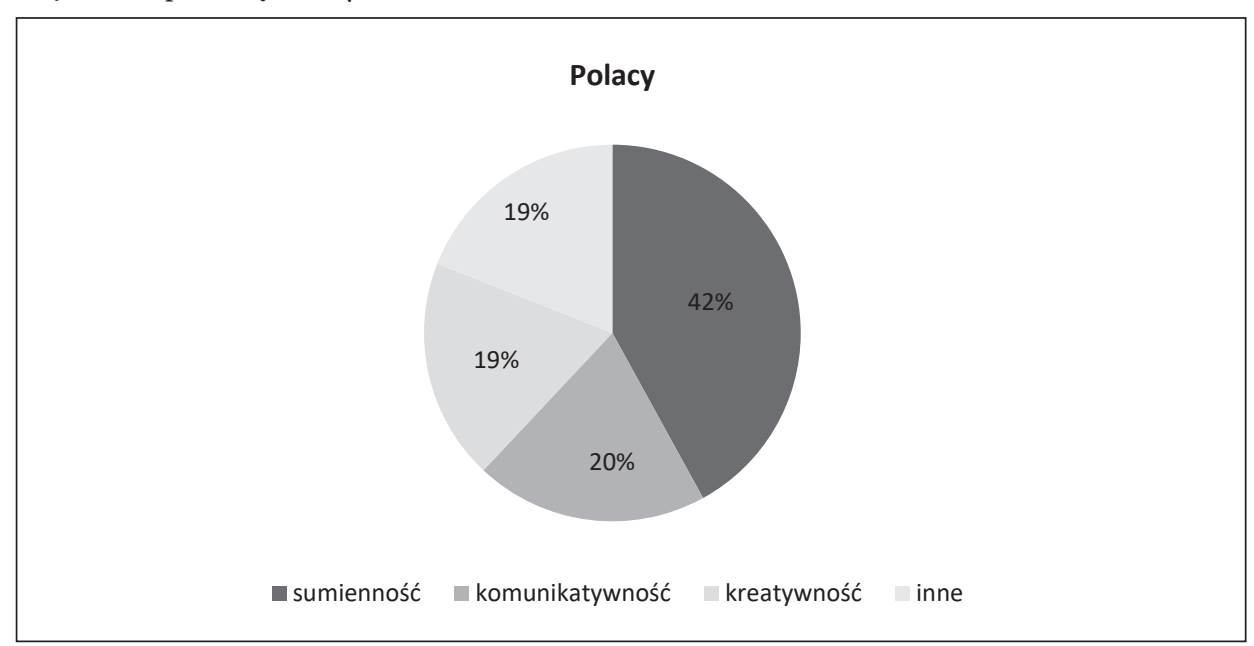

Źródło: opracowanie własne

Za pytanie dodatkowe uznano pytanie o to, czy narodowość ma znaczenie w przedsiębiorczości. Również w tym przypadku zaobserwowano w obu grupach różnice, które mają podłoże społeczno-kulturowe. Studenci niemieccy nie odpowiedzieli na to pytanie, uznając je za zbyt osobiste i nie chcąc być posądzeni o brak poprawności lub wiedzy. W przypadku grupy polskiej pytanie to nie stanowiło problemu natury formalnej, ale natury merytorycznej. Stąd aż $60 \%$ odpowiedzi to odpowiedzi „nie wiem”, a tylko $25 \%$ studentów z Polski stwierdziła, ze narodowość nie ma znaczenia. 
Trzeci problem, który został poddany analizie, to próba identyfikacji cech osobowościowych, które według badanych grup ułatwia podejmowanie aktywności przedsiębiorczej. Podobnie jak w wielu poprzednich pytaniach, również w tym przypadku zaobserwowano istotne różnice pomiędzy grupami. W obu grupach zanotowano różne, ale wyraźnie dominujące cechy. W grupie niemieckiej za najważniejszą cechę uznano umiejętności organizacyjne (rycina 3). Na taką odpowiedź wskazało 40\% wszystkich respondentów. W przypadku grupy polskiej za najważniejszą cechę uznano sumienność (42\%) (rycina 4). W obu przypadkach są to jedne z wyznaczników kodów kulturowych tych krajów, przy czym w przypadku Niemców wydaje się to dość ugruntowana cecha, a w przypadku Polaków - cecha, która ma raczej życzeniowy charakter. Za pozytywny należy uznać fakt, że obie badane grupy zwróciły uwagę na kreatywność (Polacy - 19\%, Niemcy - 18\%) jako jedną z najważniejszych cech osoby przedsiębiorczej. Ponadto polscy studenci za istotną wymienili komunikatywność (20\%), nie tylko rozumianą jako znajomość języków obcych, ale także jako umiejętność jasnego i precyzyjnego wyrażania się w mowie i w piśmie, co zastanawia w kontekście wieloletniej edukacji szkolnej, bądź komunikatywność utożsamiali z otwartością. Natomiast studenci niemieccy podkreślali znaczenie odpowiedzialności (9\%) w procesie podejmowania aktywności przedsiębiorczej.

W obu przypadkach zabrakło jednak takich cech, które wydawałyby się fundamentalne na drodze do sukcesu w biznesie. Do takich cech należy optymizm i dynamizm w działaniu, co przekłada się na pewność siebie, podejmowanie nowych wyzwań, pracowitość oraz bogate zasoby emocjonalne i intelektualne, których konsekwencjami są kreatywność, asertywność itp. Wydaje się, że pozostałe cechy są wtórne wobec tych wymienionych.

\section{Wnioski}

Przechodząc do wniosków szczegółowych wynikających bezpośrednio z przeprowadzonych badań, należy stwierdzić, że mimo kilku podobieństw istnieją duże różnice w aktywności przedsiębiorczej polskich i niemieckich studentów. Podział ten wynika przede wszystkim z różnicy w krajowych uwarunkowaniach społeczno-ekonomicznych i kulturowych, które silnie determinują postawy, intencje i zachowania przedsiębiorcze. Istniejące różnice dotyczą również pojmowania przedsiębiorczości studenckiej na poziomie formalnym i mentalnym (pobudzanie przedsiębiorczości). Uczniowie niemieccy na skutek pewniejszej ścieżki przyszłej kariery zawodowej odwlekają proces kreowania postaw przedsiębiorczych, co (uwzględniając czynnik losowy) może mieć w przyszłości bardzo negatywne konsekwencje. Z kolei grupa polska, której pozycja rynkowa jest znacznie mniej korzystna, wykazuje zwiększą aktywność przedsiębiorczą, wymuszoną wieloma czynnikami, z których nadal najważniejszym jest czynnik ekonomiczny. Silny bodziec o charakterze finansowym prowokuje polskich studentów do szybszej, bardziej zdeterminowanej, chociaż czasem powierzchownie podjętej decyzji dotyczącej określonych zachowań przedsiębiorczych. To dlatego skala i zakres aktywności przedsiębiorczych w małym stopniu nawiązują do podjętego kierunku studiów. W przypadku studentów z Niemiec bodziec ten ma zdecydowanie mniejsze znaczenie, a zgłaszane intencje i zachowania przedsiębiorcze wydają się być bardziej przemyślane.

Niewątpliwy wpływ na uzyskane wyniki ma specyfika opisywanych studiów, które chociaż istotne dla krajowego rynku pracy, nie gwarantują sukcesu finansowego. Niemniej jednak w przypadku Niemiec, gdzie geografia ma znacznie lepszą pozycję niż w Polsce, daje 
duże szanse na pracę w wielu instytucjach, organizacjach lub na wolnym rynku. W sposób oczywisty demotywuje to studentów niemieckich do planowania własnej działalności gospodarczej, proponując relatywnie wysokie wynagrodzenie jako pracownikom najemnym. Warto także zwrócić uwagę na inny demotywator o podłożu kulturowym, który powoduje znaczne ograniczenie inwencji przedsiębiorczej młodych Niemców. Chodzi o powszechne przekonanie, że „nie można robić dobrze dwóch rzeczy naraz”. Stąd niski odsetek niemieckich studentów podejmujących prace zarobkowe. Nakłada się na to znacznie wyższy poziom zamożności rodzin niemieckich studentów oraz rozbudowany system wsparcia stypendialnego. Pozostaje jeszcze wspomniany wcześniej czynnik psychologiczny, którego rola w postaci własnych ambicji i niezależności rośnie wśród polskich studentów, a w przypadku studentów niemieckich nie odgrywa tak dużego znaczenia.

Przeprowadzona analiza porównawcza dotycząca postaw przedsiębiorczych studentów geografii i kierunków pokrewnych z Polski (Szczecin) i Niemiec (Eberswalde i Greifswald) skłania do przyjęcia tezy, że normy społeczne i kody kulturowe obowiązujące w różnych społeczeństwach determinują aktywność przedsiębiorczą studentów i wpisują się jednocześnie w bardzo ogólną tezę o różnorodności kulturowej świata. Przyjęta teza znajduje również potwierdzenie w wielu innych badaniach dotyczących postaw i aktywności gospodarczej w Polsce i Niemczech. Za szczególnie ważną, a jednocześnie zbieżną z opinią autorów, należy uznać wypowiedź K. Garlacz-Sobczyk: „polscy i niemieccy biznesmeni mają odmienny kontekst poznawczy wynikający z wychowania w innej kulturze, indywidulanych, społecznych i historycznych doświadczeń, co ma wpływ na sposób ich myślenia. W odmienny sposób organizują czy też interpretują informacje, co uzależnione jest od stosowanych przez nich schematów poznawczych: postrzegania siebie, stereotypów czy też uprzedzeń" (Garlacz-Sobczyk, 2013: 81).

Uzyskane wyniki wskazują na konieczność kontynuowania badań w skali międzynarodowej, ponieważ mimo powszechnej zgody co do istoty przedsiębiorczości i konieczności upowszechniania wiedzy oraz umiejętności z nią związanych w UE, istniejące różnice ekonomiczne, ale przede wszystkim społeczno-kulturowe, powodują odmienne interpretacje przedsiębiorczości nie na poziomie dysputy akademickiej, lecz studenckiej codzienności. Interesujące byłoby również badanie młodzieży studenckiej studiującej w międzynarodowych grupach rówieśniczych. Mogłoby ono pomóc w lepszym zrozumieniu intencji i działań przedsiębiorczych obcokrajowców chcących podjąć aktywność gospodarczą w naszym kraju.

Literatura

References

Czyżewska, M. (2018). Uwarunkowania rozwoju przedsiębiorczości studenckiej na podstawie badań empirycznych. Studia i Prace. Kolegium Zarzadzania i Finansów, 160, 29-44.

Garlacz-Sobczyk, K. (2013). Zakłócenia w polsko-niemieckiej komunikacji biznesowej. Sosnowiec: Uniwersytet Śląski.

Łada, A. (2018). Trudne partnerstwo. Polacy i Niemcy o kraju sąsiada, wspólnej historii i Europie. Warszawa: Instytut Spraw Publicznych.

Łuczka, T. (2011). Przedsiębiorczość i postawy przedsiębiorcze studentów - wybrane aspekty. Ekonomiczne Problemy Ustug, 63, 150-158.

Nowaczyk, G., Sobczak, A. (2019). Przedsiębiorczość w kształceniu studentów, dorosłych i seniorów. W: T. Rachwał (red.), Kształtowanie kompetencji przedsiębiorczych. Warszawa: FRSE. 
Ostoj, I. (2016). Motywy podejmowania pracy przez studentów studiów stacjonarnych - wyniki badań. Studia i Prace WNEiZ US, 44(1), 231-241. doi: 10.18276/sip.2016.44/1-19

Osóch, B., Czapliński, P. (2019). Państwowość jako determinanta intencji przedsiębiorczych młodzieży licealnej uczącej się w międzynarodowej grupie rówieśniczej (na przykładzie Szczecin International School). Przedsiębiorczość - Edukacja [Entrepreneurship - Education], 15(1), 61-74. doi: $10.24917 / 20833296.151 .5$

Komisja Europejska. Dyrekcja Generalna ds. Przedsiębiorstw i Przemysłu. (2008). Przedsiębiorczość w szkolnictwie wyższym, szczególnie na studiach nieekonomicznych. Bruksela: Komisja Europejska.

Rachwał, T. (2019). Finanse jako element edukacji o przedsiębiorczości. Bank, IX, 110-111.

Roszkowska-Mądra, B., Parfieniuk, A., Studnicki, M. (2014). Poglądy młodzieży akademickiej studiów ekonomicznych o przedsiębiorczości i determinantach jej rozwoju. Optimum. Studia Ekonomiczne, 6(72), 217-235.

Safin, K. (2014). Przedsiębiorcze zachowania studentów - stan i konsekwencje dla dydaktyki. Horyzonty Wychowania, 13(26), 327-337.

Ścibiorska-Kowalczyk, I. (2017). Kultura ekonomiczna w Niemczech na przykładzie Euroregionu Nysa. Pogranicze. Polish Borderlands Studies, 5(2), 135-157.

Timmons, J.A. (1999). New Venture Creation: Entrepreneurship for the 21st Century. Boston: Irwin/ McGraw-Hill.

Wojciechowski, K. (2005). Jak postępować $z$ Niemcami w biznesie i nie tylko/Knigge für deutsche Unternehmer in Polen. Poznań: UAM.

Paweł Czapliński, dr hab. prof. US, Uniwersytet Szczeciński, Instytut Gospodarki Przestrzennej i Geografii Społeczno-Ekonomicznej, Katedra Geografii Społeczno-Ekonomicznej. Autor publikacji i monografii z zakresu transformacji struktur przestrzennych przemysłu Polski północnej, funkcjonowania i perspektyw rozwoju przemysłu przetwórstwa rybnego w Polsce, przedsiębiorczości młodzieży i osób starszych oraz wybranych aspektów z zarządzania i administracji samorządowej.

Paweł Czapliński, DSc, associate professor, University of Szczecin, Institute of Spatial Management and Socio-Economic Geography, Department of Socio-Economic Geography. Author of publications and monographs in the field of the transformation of spatial structures of the Northern Poland industry, functioning and development perspectives of the fish processing industry in Poland, entrepreneurship of youth and the elderly, as well as selected aspects of management and local government administration.

ORCID: https://orcid.org/0000-0001-5093-941X

\author{
Adres/Address: \\ Uniwersytet Szczeciński \\ Instytut Gospodarki Przestrzennej i Geografii Społeczno-Ekonomicznej \\ Katedra Geografii Społeczno-Ekonomicznej \\ ul. Mickiewicza 18 \\ 70-383 Szczecin, Polska \\ e-mail: pawel.czaplinski@usz.edu.pl
}

Barbara Osóch, dr, jest wieloletnim pracownikiem Uniwersytetu Szczecińskiego. Na tamtejszym uniwersytecie otrzymała tytuł magistra geografii i doktora nauk o Ziemi w dyscyplinie geografia. Szerokie zainteresowania z zakresu geografii społecznej, socjologii, turystyki wodnej zostały przedstawione w licznych publikacjach naukowych. Głównym obszarem zainteresowań naukowych jest rozwój przestrzeni geograficznej na potrzeby turystyki wodnej, żeglarstwa rekreacyjnego i struktury społecznej uczestników różnych form aktywności turystycznej. 
Barbara Osóch, $\mathrm{PhD}$, she is a long-term employee of the University of Szczecin. At the University she has graduated from Geography and received a $\mathrm{PhD}$ in Earth Sciences. Extensive interests in the field of social geography, sociology, water tourism have been presented in numerous scientific publications. The main area of academic interest is the development of geographical space for the purposes of water tourism, recreational sailing and social structure of participants in various forms of tourist activity.

ORCID: https://orcid.org/0000-0002-8364-7904

\section{Adres/Address:}

Uniwersytet Szczeciński

Instytut Gospodarki Przestrzennej i Geografii Społeczno-Ekonomicznej

Katedra Geografii Społeczno-Ekonomicznej

ul. Mickiewicza 18

70-383 Szczecin, Polska

e-mail: barbara.osoch@usz.edu.pl 